\title{
AL-ISLÂM WA USHÛL AL- DELEGITIMASI INSTITUSI KHILÂFAH
}

\author{
Harir Muzakki
}

\author{
Judul: Al-Islâm wa Ushûl al- $\underline{\text { Hukm }}$ \\ Penulis: 'Alî 'Abd al-Râziq \\ Penerbit: Mathba'ah Mishr, Mesir, 1925 \\ Tebal: 201 Halaman
}

SETELAH peristiwa penghapusan institusi khilâfah oleh Mustafa Kemal Attaturk di Turki tahun 1924, 'Alî 'Abd al-Râziq memberikan sumbangan pemikirannya dengan menulis buku yang berjudul Al-Islâm wa Ushûl al- $\underline{H} u k m$ (Islam dan Dasar-dasar Pemerintahan) tahun 1925. Buku tersebut merupakan reaksi atas penghapusan sistem khilâfah. Sementara itu, Rasyîd Ridlâ dan kawan-kawannya dari al-Azhar sedang bersemangat mempersiapkan muktamar Akbar Islam di Kairo dalam rangka menghidupkan kembali lembaga khilâfah. ${ }^{1}$ Munculnya buku itu menimbulkan polemik dan perdebatan di kalangan masyarakat ilmiyah Mesir, bahkan negara-negara Arab dan dunia Islam pada umumnya.

Karya al-Râziq tersebut dipandang sebagai tuntutan dihapuskannya sistem khilâfah yang telah mentradisi di kalangan umat Islam dan sekaligus mengingkari eksistensi khilâfah dalam ajaran Islam. Karya itu pada intinya membahas hubungan antara agama dan politik atau Islam dan negara. Persoalan utamanya diawali dari discourse posisi Muhammad saw sebagai seorang rasul semata ataukah juga sebagai kepala negara. Selanjutnya, seputar khilâfah itu sendiri, apakah Muhammad sebagai khalifah dan kedudukannya bisa digantikan para khalifah setelah Muhammad atau tidak. Kemudian, di bagian akhir, menyoal sistem pemerintahan masa Muhammad, bisakah sistem tersebut diterapkan di masa berikutnya. Ketiga hal itulah yang menjadi perhatian utama al-Râziq.

${ }^{1}$ Muhamad Azhar, Filsafat Politik: Perbandingan Antara Islam dan Barat (Jakarta: RajaGrafindo Persada, 1996), 112. 


\section{Latar Sosial dan Intelektual al-Râziq}

'Alî 'Abd al-Râziq lahir pada tahun 1888 di sebuah desa yang bernama alSaid, wilayah Mania, Mesir. Ayahnya bernama 'Abd al-Râziq Pasya, seorang feodal yang aktif dalam bidang politik dan pembesar terpandang di Mesir pada waktu itu. Ayahnya juga seorang pasya besar yang memiliki pengaruh dan tanah yang sangat luas.

Al-Râziq termasuk atau paling tidak bisa dikelompokkan sebagai pengikut Muhammad 'Abduh sekalipun tidak sempat belajar banyak darinya. Ketika 'Abduh meninggal dunia tahun 1905, ia berusia tujuh belas tahun. ${ }^{2}$ Dia memperoleh pendidikan agama Islam di Universitas Islam al-Azhar pada usia yang masih amat muda, sepuluh tahun. Dia belajar hukum kepada Syaykh Ahmad Abû Khathwah, sahabat 'Abduh. Keduanya sama-sama pernah berguru kepada Jamâl al-Dîn al-Afghânî. Sejak tahun 1910, ketika berusia dua puluh tahun, al-Râziq juga mengikuti perkuliahan di Jâmi'ah alMishriyyah (atau sekarang dikenal dengan Universitas Kairo) selama hampir dua tahun. Di antara dosen asing di universitas itu adalah Santilana yang memberikan kuliah Sejarah Filsafat dan Nallino yang mengajar Sejarah Sastra Arab. ${ }^{3}$

Setelah al-Râziq mendapatkan ijazah 'Aliyah dari al-Azhar tahun 1911, pada tahun 1912 ia memberikan kuliah retorika dan sejarah perkembangan sebagai salah satu ilmu bahasa Arab di al-Azhar. ${ }^{4}$ Selanjutnya, ia pergi belajar di Universitas Oxford, Inggris untuk menekuni bidang politik dan ekonomi. Seiring dengan pecahnya Perang Dunia I, ia langsung kembali ke Mesir tahun 1914. Sekembalinya dari Inggris, dia langsung diangkat menjadi hakim Mahkamah Syariah di daerah al-Manshûrah, Mesir. Setelah melontarkan pendapat tentang khilâfah-yang berseberangan dengan pendapat para ulama pada masa itu-, dia dikucilkan oleh Dewan Ulama al-Azhar dan diberhentikan dari jabatan hakim, serta dilarang memangku jabatan apapun dalam pemerintahan. Dia meninggal dunia pada tanggal 22 September 1966 ketika berusia 78 tahun.

${ }^{2}$ Munawir Sjadzali, Islam dan Tata Negara: Ajaran, Sejarah, dan Pemikiran (Jakarta: UIPress, 1990), 24.

3IAIN Syarif Hidayatullah, Ensiklopedi Islam Indonesia (Jakarta: Djambatan, 1992), 102.

${ }^{4}$ A. Latif Mukhtar, "Ali Abd al-Raziq (Masalah Negara dalam Islam)," dalam Gerakan Kembali ke Islam (Bandung: Rosdakarya, 1998), 84. 


\section{Kedudukan Muhammad}

Apakah Muhammad sebagai seorang rasul semata atau juga sebagai kepala negara? Masalah itu merupakan persoalan mendasar yang harus dijawab. Mayoritas ulama dan kaum muslimin mengakui bahwa Muhammad adalah rasul Allah, sekaligus juga sebagai kepala negara. Namun, al-Râziq menyanggah pendapat mayoritas kaum muslimin itu, dan menyatakan bahwa Muhammad hanya sebagai rasul Allah. Dalam karyanya, ia menjelaskan kedudukan Muhammad secara panjang lebar sebagai rasul yang ia perkuat dengan berjajar kutipan ayat al-Qur'an.

Menurut al-Râziq, Muhammad hanyalah seorang rasul yang bertugas menyampaikan seruan agama (dakwah) tanpa disertai kecenderungan terhadap kekuasaan maupun kedudukan sebagai seorang raja. Muhammad bukanlah seorang penguasa maupun pemegang tampuk pemerintahan. Dia tidak pernah mendirikan suatu negara dalam pengertian yang selama ini berlaku dalam ilmu politik. Dia bukanlah seorang raja, pendiri suatu negara maupun penganjur berdirinya suatu negara, ataupun suatu pemerintahan politik. 5

Al-Râziq menyatakan bahwa sepanjang hidupnya Muhamad tidak pernah memberikan isyarat apapun berkaitan dengan "negara Islam" atau "negara Arab". Kalau mendirikan negara termasuk tugasnya, bagaimana mungkin dia meninggalkan kaum muslimin tanpa petunjuk yang jelas tentang negara dan akhirnya mereka terjerumus dalam kebingungan dan saling berbunuhan. ${ }^{6}$ Meskipun demikian, risâlah sendiri pada dasarnya menuntut Muhammad untuk memiliki semacam kepemimpinan dan kekuasaan atas bangsanya. Kepemimpinan Muhammad adalah kepemimpinan keagamaan yang diperoleh melalui tugas kerasulan dan berhenti tepat saat ajal menjemputnya. ${ }^{7}$ Ia menegaskan bahwa kekuasaan semacam itu (kerasulan) sedikitpun tidak sama dengan kekuasaan seorang raja atas rakyatnya. Seorang rasul harus memiliki kesempurnaan lahir dan batin, serta memiliki banyak kelebihan dalam status sosial sehingga perintahnya selalu dilaksanakan dan ajarannya pasti ditaati (Qs. al-Nisâ' [4]: 64).

5‘Ali 'Abd al-Râziq, Al-Islâm wa Ushûl al- $\underline{H} u k m$ (Mesir: Mathba'ah Mishr, 1925), 87.

${ }^{6}$ Ibid.

${ }^{7}$ Di Qs. al-Ahzâb (33): 40 disebutkan pula bahwa Muhammad adalah penutup para nabi. 
Al-Râziq membedakan antara kekuasaan rasul dan kekuasaan para raja, ataupun kekuasaan lainnya di dunia. Kekuasaan rasul adalah kepemimpinan dakwah menuju agama Allah dan tugas menyampaikan risâlah-Nya. Hal itu bukanlah kepemimpinan seorang raja, melainkan risâlab sekaligus agama-pemerintahan kenabian dan bukan pemerintahan kaisar. Kekuasaan seorang rasul atas umatnya bersifat rohaniah dan sumbernya adalah keimanan yang ada dalam hati sehingga melahirkan ketundukan sejati dan sempurna yang disertai ketundukan fisik. Kekuasaan rasul berfungsi sebagai pemberi petunjuk menuju agama Allah. Sementara, kekuasaan raja hanya bersifat fisik yang berpijak pada ketundukan jasmaniah dan sedikitpun tidak berhubungan dengan hati nurani. Kekuasaan raja berfungsi untuk kebahagiaan manusia di dunia semata.

Al-Qur'an menyatakan bahwa Rasulullah tidak ada sangkut-pautnya dengan kekuasaan politik. Ayat-ayat terkait satu sama lain saling meneguhkan bahwa tugas Ilahi yang diemban Rasulullah tidak melampaui batas-batas yang bisa mencakup arti kekuasaan duniawi (raja). Hal itu dinyatakan dalam Qs. al-Nisầ' (4): 80 yang diperkuat oleh Qs. al-Anfâl (8): 7-8, al-An'âm (6): 11.

Al-Qur'an secara tegas menolak untuk mengakui Rasulullah sebagai pemelihara, penjaga, pemaksa, dan orang yang memiliki hak untuk memaksa manusia agar beriman. ${ }^{8}$ Al-Râziq menyimpulkan bahwa barangsiapa yang bukan pemelihara, pengatur, dan pemaksa bukanlah seorang raja. Hak seorang raja, antara lain, mengatur masyarakat, memiliki kekuasaan memaksa, dan juga kedaulatan yang tidak terbatas. Seseorang yang tidak bisa dikatakan sebagai pemelihara, maka dia tidak bisa disebut raja. Berkaitan dengan hal itu, Allah berfirman dalam Qs. al-Ahzzâb (33): 40, ${ }^{9}$ Qs. al-A'râf (7): 188, ${ }^{10}$ dan Qs. al-Mầidah (5): $92 .{ }^{11}$

${ }^{8}$ Lihat Qs. al-Baqarah (2): 256.

${ }^{9}$ Artinya: "Muhammad itu sekali-kali bukanlah bapak dari seorang laki-laki di antara kamu, tetapi dia adalah Rasulullah dan penutup nabi-nabi."

10Artinya: "Katakanlah: "Aku tidak berkuasa menarik kemanfaatan bagi diriku dan tidak (pula) menolak kemudharatan kecuali yang dikehendaki Allah. Dan sekiranya aku mengetahui yang ghaib, tentulah aku membuat kebajikan sebanyak-banyaknya dan aku tidak akan ditimpa kemudharatan. Aku tidak lain hanyalah pemberi peringatan, dan pembawa berita gembira bagi orang-orang yang beriman'.”

${ }^{11}$ Artinya: "Dan taatlah kamu kepada Allah dan taatlah kamu kepada Rasul (-Nya) dan berhati-hatilah. Jika kamu berpaling, maka ketahuilah bahwa sesungguhnya kewajiban Rasul Kami hanyalah menyampaikan (amanat Allah) dengan terang." 


\section{Khilâfah}

Al-Râziq tidak banyak memberikan sumbangan pemikiran tentang khilâfah. Dia banyak menukil pendapat ulama sebelumnya dan mendeskripsikan khilâfah dalam wacana pemikiran politik Islam, kemudian menyimpulkan dan menjustifikasi pendapat mereka. Para ulama memandang bahwa kedudukan dan otoritas para khalifah sepadan dengan nabi dan mendirikan khilâfah hukumnya wajib berdasarkan ijmấ. Kedua pendapat itulah yang disangkal al-Râziq. Dia mendefinisikan khilâfah secara bahasa maupun istilah, kemudian menyebutkan pendapat para ulama tentang khilâfah, kedudukan, dan otoritas khalifah.

Menurut al-Râziq, kata "khilâfah" berasal dari mashdar "takhallafa" yang berarti mengikuti di belakang orang lain dan menggantikan tempatnya. Definisi ini didasarkan pada Qs. al-Zukhruf (43): 60.12 Berdasarkan definisi itu, khalifah berarti pengganti orang lain karena absennya orang yang digantikan, meninggal dunia, ketidakmampuan, maupun karena alasan-alasan lain. Khalifah juga berarti al-sulthân al-a'̧̧̧̧am (kekuasaan paling tinggi, paling besar).

Adapun menurut istilah, kata "khilâfah" memiliki kesamaan arti dengan "imâmah", yakni kepemimpinan menyeluruh dalam masalah agama dan dunia sebagai pengganti Rasulullah. Sebagian ulama berpendapat bahwa khalifah adalah pengganti Rasulullah yang sewaktu hidupnya menangani masalah keagamaan yang diterimanya dari Allah untuk disampaikan dan mengajak umat manusia mengikuti ajaran-Nya. Allah telah memilih orang, sebagai pengganti Muhammad, yang bertugas memelihara pelaksanaan ajaran agama dan urusan politik duniawi.

Para ulama memandang bahwa kedudukan khalifah di hadapan rakyatnya sepadan dengan kedudukan Rasulullah di tengah-tengah kaum muslimin. Ia memiliki kekuasaan menyeluruh dan memiliki hak untuk ditaati secara sempurna, serta memiliki hak dan wewenang penuh mengurus persoalan agama mereka. Dia harus melaksanakan fungsinya di tengah-tengah umat dalam batas yang telah ditetapkan agama. Dia juga memiliki hak mengatur urusan duniawi umatnya. Sementara rakyat harus taat lahir dan batin karena patuh kepada pemimpin berarti taat kepada Allah dan membangkang kepada pemimpin berarti membangkang kepada Allah. Mengikuti petunjuk imam

12Artinya: "Dan kalau Kami kehendaki benar-benar Kami jadikan sebagai gantimu di muka bumi malaikat-malaikat yang turun temurun". 
dan menaati perintahnya merupakan kewajiban. Kalau seseorang tidak mengikuti imâm (pemimpin), maka imannya tidak bisa dikatakan sempurna dan keislamannya tidak diakui. Pendapat para ulama itu dibantah al-Râziq.

Al-Râziq mengungkapkan bahwa tidak semua orang yang dituduh murtad benar-benar murtad dalam arti kafir kepada Allah dan rasul-Nya. Salah satu contoh faktual yang ia ajukan adalah kasus pembangkangan sementara umat pada kepemimpinan khalifah Abû Bakr. Mereka berpendirian bahwa tidak tunduk terhadap kepemimpinan Abû Bakr tidak akan mempengaruhi dan mengancam agamanya. Perang yang dilancarkan Abû Bakr semata-mata perang politik sebagai upaya mempertahankan persatuan Arab dan melindungi negara dari ancaman. Orang-orang yang tidak mau membayar zakat tidak bermaksud membangkang perintah agama atau menolak ajaran Islam, melainkan tidak mau menaati perintah Abû Bakr. Karena itu ketika Khâlid bin Wâlid berusaha membunuh Mâlik bin Nuayrah karena yang bersangkutan termasuk kelompok orang yang menolak membayar zakat dan dicap murtad, Mâlik mengatakan kepada Khâlid bahwa dirinya tetap muslim, hanya saja tidak mau membayar zakat melalui Khâlid (Abû Bakr). ${ }^{13}$

\section{Hukum Mendirikan Khilâfah}

Para ulama berpendapat bahwa mendirikan khilâfah hukumnya adalah wajib berdasarkan ijmấ. Mereka memiliki dua argumentasi: pertama, ijmấ para sahabat dan tabi'in setelah wafatnya Rasulullah, yakni mereka membaiat Abû Bakr; kedua, adanya fungsi seorang imam sesuai dengan nash ajaran agama dan kepentingan umat semisal melaksanakan al-amr bi al-ma'rûf wa al-naby 'an al-munkar. Pendapat para ulama diperkuat dengan dua ayat al-Qur'an, yaitu Qs. al-Nisâ' (4): $59^{14}$ dan Qs. al-Nisâ' (4): 83. ${ }^{15}$

Menurut ahli tafsir, ulû al-amr berarti para pemimpin kaum muslimin pada masa Rasulullah, masa setelahnya termasuk para khalifah, para

\section{Ibid., 60.}

${ }^{14}$ Artinya: "Hai orang-orang yang beriman, taatilah Allah dan taatilah Rasul (-Nya), dan ulil amri di antara kamu. Kemudian jika kamu berlainan pendapat tentang sesuatu, maka kembalikanlah ia kepada Allah (al-Qur'an) dan Rasul (sunnahnya), jika kamu benar-benar beriman kepada Allah dan hari kemudian. Yang demikian itu lebih utama (bagimu) dan lebih baik akibatnya."

${ }^{15}$ Artinya: "Dan kalau mereka menyerahkannya kepada Rasul dan Ulil Amri di antara mereka, tentulah orang-orang yang ingin mengetahui kebenarannya (akan dapat) mengetahuinya dari mereka (Rasul dan Ulil Amri)". 
panglima perang, dan para ulama. Al-Râziq menafsirkan ulû al-amr pada ayat di atas adalah para pembesar sahabat yang memahami seluk-beluk persoalan umat atau menjadi pemimpin mereka. Menurutnya, kandungan maksimal ayat di atas adalah keharusan kaum muslimin memiliki sekelompok orang yang dapat dijadikan tempat rujukan atas persoalan-persolan yang mereka hadapi sehingga tidak tepat ayat itu dijadikan dasar wajibnya mendirikan kbilâfah. ${ }^{16}$

Untuk memperkuat argumen tersebut, para ulama juga mengutip badîts shabîh, semisal hadits yang artinya: "Barangsiapa yang mati dan tidak pernah berbaiat, maka ia mati dalam keadaan jabiliab", dan hadits yang diriwayatkan alBukhârî dan Muslim, "Tetaplah berada dalam jamaah dan imam kaum muslimin". Al-Râziq tidak mempermasalahkan kesahihan hadits itu, tetapi menggali makna yang lebih dalam. Seandainya maksud baiat dalam hadits itu membaiat khalifah dan yang dimaksud jamaah adalah pemerintahan Islam, maka hal itu bukan termasuk masalah 'aqîdah syar'iyyah dan/atau salah satu di antara hukum Islam. ${ }^{17}$

\section{Sistem Pemerintahan Masa Rasulullah}

Setelah menguraikan posisi Muhammad semata-mata sebagai seorang rasul dan di sisi lain Muhammad memiliki kekuasaan atas umatnya yang sama sekali tidak sama dengan raja atau kepala negara, selanjutnya al-Râziq menjelaskan masalah khilafah. Menurutnya Muhammad adalah seorang khalifah yang tak mungkin digantikan oleh siapapun karena otoritas itu berasal dari kerasulannya.

Menurut al-Râziq, meski pada masa Nabi Muhammad sistem pemerintahan telah ada, tetapi masalahnya sangat pelik untuk dikaji karena diliputi halimun dan dinding tebal. Pelaksanaan hukum dalam pengertian pemerintahan sudah ada sejak jaman $\mathrm{Nabi}^{18}$ sebagaimana terdapat di kalangan bangsa Arab dan bangsa lain pra-Islam. Dalam beberapa hadîts

${ }^{16}$ Ibid., 17.

${ }^{17 L e b i h ~ l a n j u t ~ a l-R a ̂ z i q ~ m e n j e l a s k a n ~ b a h w a ~ b a n y a k ~ f i r m a n ~ A l l a h ~ y a n g ~ m e n y i n g g u n g ~}$ masalah thalâq, utang piutang, jual beli, dan sebagainya, serta mengemukakan hukum berbagai persoalan. Akan tetapi, semuanya itu bukan berarti masalah kewajiban agama, begitu pula ketika Nabi mengemukakan aturan hukum seputar masalah baiat, pemerintahan, dan menaati ulu al-amr. Lihat Ibid., 18.

${ }^{18}$ Namun, sulit menyimpulkan secara pasti prosedur penetapan hukum yang diambil oleh Nabi. Ibid., 44. 
shabîh dapat ditemukan petunjuk bagaimana cara Nabi Muhammad memutuskan persoalan hukum, tetapi sulit untuk menetapkan hukum yang dipakai Nabi. Hal itu disebabkan tidak adanya gambaran yang cukup jelas tentang proses pengambilan hukum yang ditetapkan Nabi dan bagaimana sistem yang ia kepalai dilangsungkan. ${ }^{19}$

Salah satu gambaran yang paling jelas mengenai pemerintahan yang ada pada masa Rasulullah adalah jibâad. Jihad bukanlah semata-mata dipergunakan sebagai sarana pengembangan agama dan menggiring umat manusia menuju keimanan kepada Allah dan rasul-Nya, tetapi juga sebagai sarana untuk menunjukkan justifikasi kekuasaan dan ekspansi wilayah kerajaan. Jihad merupakan salah satu di antara banyak ciri negara Islam dan citra yang menampilkan sosok sebuah kerajaan. Menurut al-Râziq, pemerintahan Rasulullah merupakan tugas yang terpisah dari dakwah Islam dan berada di luar tugas risâlah.

Tentang bagaimana Nabi membentuk negara dan seperti apa pula sistem pemerintahannya sejauh ini masih menjadi permasalahan bagi umat Islam. Meskipun demikian, al-Râziq mengakui bahwa sistem pemerintahan periode Rasulullah memang nyata ada dan telah mencapai bentuknya yang paling sempurna dalam bentuk negara yang diatur Rasulullah melalui bimbingan wahyu. Hanya saja tidak diketahui secara rinci, bagaimana model dan sistem pemerintahan Rasulullah. ${ }^{20}$ Itulah mengapa ia pun tegaskan bahwa pada dasarnya Islam tidak menentukan sistem politik tertentu. Umat Islam absah dan boleh-boleh saja mengambil sistem politik demokrasi, diktator, republik, atau lainnya. Kbilafah bukanlah sistem politik yang islami. Bahkan, bagi alRâziq, kbilafah merupakan institusi politik Islam yang ketinggalan zaman dan hanya menimbulkan bencana bagi umat Islam. Institusi politik Islam itu hanya ada pada masa Rasulullah dalam bentuknya yang sempurna. Salah satu ciri menonjol dari pemerintahannya adalah jihad. Abû Bakr bukanlah khalifah pertama, melainkan sekedar khalifah Rasulullah yang gaya kepemimpinannya meniru Rasulullah.

${ }^{19}$ Al-Râziq mencontohkan pengiriman 'Alî ke Yaman. Dalam suatu riwayat, 'Alî bertugas sebagai hakim, sementara riwayat yang lain dia bertugas sebagai pemungut zakat seperlima harta; demikian juga riwayat tentang pengiriman $\mathrm{Mu}^{\text {‘âdz }}$ sebagai hakim atau panglima perang atau sebagai pengajar.

${ }^{20}$ Tidak ada informasi yang cukup mengenai fungsi-fungsi pemerintahan, seperti masalah keuangan dan pengawasannya, keamanan jiwa dan harta (kepolisian). Ibid., 45. 
Agama Islam yang dibawa Rasulullah adalah rahmat bagi seluruh umat manusia. Namun, kata al-Râziq, menyatukan umat Islam dalam satu ikatan politik merupakan sesuatu yang mustahil. Sebab, mereka memiliki beragam budaya dan di antara mereka tinggal di suatu bangsa yang plural agamanya, terdiri dari berbagai macam suku yang tradisi dan budayanya berbeda.

\section{Menimbang Pemikiran Politik al-Râziq}

Gagasan al-Râziq yang memandang Muhammad semata-mata sebagai seorang nabi menjadi pandangan yang sangat radikal dan berlawanan dengan mainstream pemikiran politik Islam. Dia ingin memisahkan dan membedakan secara ekstrem antara kekuasaan kenabian dan kekuasaan seorang raja. Konsekuensinya, dia menafikan kbilâfah dan sistemnya karena misi Muhammad sama sekali tidak ada kaitannya dengan politik dan negara. Menurut Maryam Jameelah, al-Râziq adalah sarjana muslim yang pertama kali membuka wacana sekularisme Islam. ${ }^{21}$ Tampaknya al-Râziq hendak menyucikan dakwah Islam meskipun dalam realitas sejarah, negara Madinah terbentuk pada periode kedua kenabian.

Misi kerasulan Muhammad berlangsung selama 23 tahun yang terbagi ke dalam dua periode: Makkah selama tiga belas tahun dan Madinah selama sepuluh tahun. Masing-masing periode memiliki perbedaan materi dakwah dan strategi penyampaian risalab yang disebabkan kondisi masyarakat yang berbeda. Misi utama dakwah Nabi di Makkah membenahi masalah 'aqîdah dan moral. Ayat-ayat yang turun di Makkah berisi ajaran tawhîh, keimanan kepada Allah, malaikat, rasul, dan akhirat. ${ }^{22}$ Ayat-ayat tentang moral menekankan keluhuran jiwa, keharusan manusia menjauhkan diri dari tipu daya dunia dan perhiasannya.

'Aqîdah dan moral memiliki hubungan yang sangat erat. Inti 'aqîdah adalah ajaran tawhîd yang berimplikasi terhadap kehidupan sosial dan moralitas masyarakat. Doktrin tawhîd berimbas pada kemakmuran roda perdagangan kaum Quraisy yang ditegakkan atas dasar eksploitasi kaum

${ }^{21}$ Lihat Maryam Jameelah, Islam and Modernism (Lahore: M. Yusuf Khan Publisher, 1977), 170.

22Dengan ungkapan yang berbeda Nourouzzaman Shiddiqi mengatakan bahwa ayatayat yang turun di Mekkah mengenai masalah-masalah eskatologis, harapan memperoleh pahala bagi orang yang beriman dan berbuat baik dan ancaman siksa neraka bagi orang yang tidak beriman dan berbuat jahat. Nouruzzaman Shiddiqi, Jeram-jeram Peradaban Muslim (Yogyakarta: Pustaka Pelajar, 1996), 84. 
lemah. ${ }^{23}$ Gagasan-gagasan yang terkandung dalam ajaran agama yang dibawa Muhammad mampu mengatasi situasi masyarakat Makkah kala itu secara keseluruhan. Kemakmuran yang mendasarkan diri pada kepentingan komersial telah mengakibatkan munculnya aneka penyakit sosial. Ketegangan yang berupa benturan antara kepentingan komersial dan adat istiadat nomadik cukup banyak mempengaruhi sebagian besar penduduk Makkah. Pemikiran keagamaan dari al-Qur'an ditujukan pada akar-akar keagamaan yang terkait dengan penyakit sosial masa itu yang menjalar di seluruh kehidupan ekonomi dan sosial. ${ }^{24}$ Dalam pada itu dakwah Nabi di Makkah kerap mendapatkan intimidasi dan perlawanan keras dari kaum Quraisy sehingga menyebabkan Nabi kemudian memutuskan untuk hijrah ke Yatsrib.

Periode kedua kenabian atau dakwah Islam dimulai sejak Nabi hijrah ke

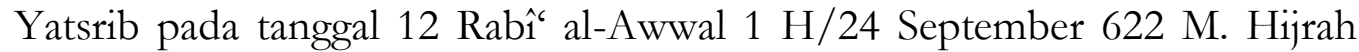
bertujuan menyelamatkan kaum muslimin agar terbebas dari tindakan kesewenang-wenangan kaum Quraisy. Menurut Thomas W. Arnold Hijrah juga merupakan gerakan strategis yang sangat tepat ketika reaksi sosial atas keadaan masyarakat Makkah yang mayoritas menolak Islam dan sekaligus sebagai respons atas fakta sosial (keadaan masyarakat) Madinah yang secara terbuka menerima seruan dakwah Rasul. ${ }^{25}$

Di kota itu, Nabi memperoleh sambutan penghormatan istimewa dengan mengubah nama kota Yatsrib menjadi Madinah al-Nabiy atau disebut alMadinah al-Munawwarah. Nabi resmi menjadi pemimpin penduduk kota itu setelah tiba dan diterima penduduk Yatsrib. Babak baru dimulai dan Islam mulai menjadi kekuatan di Madinah. Muhammad tidak hanya sebagai pemimpin agama, tetapi juga sebagai kepala negara. ${ }^{26}$ Dalam diri Muhammad terkumpul dua kekuasaan, spiritual dan duniawi.

Terbentuknya negara Madinah merupakan akibat dari perkembangan panganut Islam yang menjelma menjadi kelompok sosial dan memiliki kekuatan politik riil di bawah pimpinan Nabi. Keadaan Nabi dan umatnya segera mengalami perubahan besar, yaitu memiliki kedudukan yang baik dan segera menjadi umat yang kuat dan mandiri. Masyarakat yang baru dibentuk

${ }^{23}$ Fazlur Rahman, Islam (Chicago\&London: University of Chicago Press, 1979), 15.

${ }^{24} \mathrm{~W}$. Montgomery Watt, Islamic Thought (Edinburgh: Edinburgh University Press, 1980), 4.

${ }^{25}$ Thomas W. Arnold, The Caliphate (London: Routledge and Kegan Paul, 1965), 23.

26Ibid., 30. 
itu akhirnya menjadi satu negara yang pada akhir masa Nabi mampu menguasai hampir seluruh semenanjung Arabia.

Karena itu, kecenderungan umum sebagian intelektual muslim meyakini bahwa Islam adalah sebuah fenomena agama dan politik. Logikanya sederhana, karena pembangunnya adalah seorang nabi sekaligus politikus yang bijaksana atau negarawan. Pandangan semacam ini, hingga tingkat tertentu terepresentasikan antara lain dalam pandangan MacDonald mengatakan, "Di sini, Madinah, telah terbentuk negara Islam pertama dan meletakkan dasar-dasar politik bagi perundang-undangan Islam." 27 Juga Fazlur Rahman yang mengatakan bahwa masyarakat Madinah yang diorganisasi Nabi merupakan suatu negara dan pemerintahan yang membawa terbentuknya komunitas muslimin yang lebih kuat. ${ }^{28}$ Keyakinan keduanya, hingga tingkat tertentu, merepresentasikan

Pengertian khilâfah, menurut al-Râziq, baik dari segi bahasa maupun istilah, masih banyak celah untuk dikritik. Menurutnya, kata khilâfah berasal dari mashdar "takhallafa". Kata khilafah menurut kaedah bahasa yang benar adalah khalafa, yakhlifu, khilâfatan. Dengan demikian, kata khilâfah berasal dari mashdar"khalafa".

Dari definisi yang dikemukakan para ulama, al-Râziq memahami khalifah sebagai pengganti Rasulullah yang menangani masalah-masalah keagamaan yang diterimanya dari Allah. Selanjutnya, dia mengutip pendapat bahwa kedudukan khalifah di tengah-tengah umatnya sepadan dengan posisi Rasulullah. Menurutnya, gelar khaliffah al-Rasûl memiliki wibawa, kekuatan, dan pesona, apalagi gelar khalîfah Allâh.

Yang perlu diperhatikan, pengganti itu belum tentu sama dengan yang digantikan. Terkadang yang digantikan lebih baik dari yang menggantikan dan bisa sebaliknya. Tidaklah tepat menyepadankan Nabi dengan para penggantinya dalam hal kualitas dan otoritas Nabi yang bersifat samawi, suci, dan berasal dari Allah, dan otoritas para khalifah yang diperoleh dari umat melalui baiat. Tesis ini sejalan dengan pandangan Ibn Khaldun tentang tujuan pendirian negara, yakni untuk mengusahakan kemaslahatan agama

${ }^{27}$ D.B. MacDonald, Development of Muslim Theology, Jurisprudence, and Constitutional Theory (New York: t.p. [?], 1903), 63.

${ }^{28}$ Rahman, "The Islamic Concept of State," dalam Islam in Transition: Muslim Perspective, ed. John J. Donohue and John L. Esposito (New York: Oxford University Press, 1982), 261. 
dan dunia yang bermuara pada kepentingan akhirat. ${ }^{29} \mathrm{Hal}$ itu senafas dengan Abû al-A'lâ al-Mawdûdî yang menegaskan bahwa tujuan negara dalam Islam adalah demi menegakkan dan melaksanakan kekuasaannya dengan segenap sumber daya yang ada untuk menciptakan kehidupan yang lebih baik bagi perbaikan kehidupan manusia. ${ }^{30}$

Demikian juga dengan rumusan Rahman. Menurutnya, tujuan negara Islam adalah untuk mempertahankan keselamatan dan integritas negara sehingga setiap warga menyadari kemampuan masing-masing dan mau menyeimbangkan kemampuan demi terwujudnya kesejahteraan seluruh warga negara. ${ }^{31}$ Dengan demikian, dapat disimpulkan bahwa tujuan pemerintahan Islam ada dua: pertama, untuk melaksanakan ketentuanketentuan agama sesuai dengan perintah Allah dan rasul-Nya, menghidupkan sunnah, serta memerangi bid'ah agar seluruh umat Islam dapat menaati Allah dengan baik; kedua, mengurus masalah-masalah duniawi, seperti menghimpun dana dari sumber-sumber yang sah dan menyalurkannya kepada yang berhak, mencegah kezaliman, dan lain-lain.

Tujuan pemerintahan sedemikian terkait rekat dengan kapasitas Nabi sebagai kepala negara, pembuat hukum, dan sekaligus hakim. Alhasil, Nabi menduduki jabatan eksekutif, legislatif, dan yudikatif sekaligus. Seorang khalifah memutuskan hukum berdasarkan al-Qur'an dan hadits, baik melalui ijtihâd maupun langsung menerapkan hukum yang ada dalam al-Qur'an dan hadits. Sehingga, menyamakan posisi Nabi dengan para penggantinya atau khalifahnya tidaklah tepat.

Menurut al-Râziq, mendirikan negara hukumnya tidaklah wajib. Dalam pada itu ia menolak pendapat para ulama yang menyatakan mendirikan khilâfah hukumnya wajib atas dasar ijmâ. Dia tidak menolak ijmấ sebagai dalil untuk menetapkan hukum dan salah satu sumber hukum Islam. Yang ia tolak adalah tesis bahwa telah terjadi kesepakatan (jjmâ) di antara sahabat, tabiin, seluruh ulama, maupun seluruh umat Islam dalam masalah kekhalifahan Abû Bakr.

Di sinilah, agaknya, al-Râziq kurang tepat memahami ijmấ dalam masalah khilâfah. Ijmấ dalam persoalan itu sesungguhnya adalah kesepakatan para

${ }^{29} \mathrm{Ibn}$ Khaldun, al-Muqaddimah (Mesir: Mushthafâ Muhammad, t.th.), 124.

${ }^{30} \mathrm{Abu \hat { } \mathrm { al }}$-A'lâ al-Mawdûdî, Islamic Law and Constitution (Lahore: Islamic Publication Ltd., 1975), 216-7.

${ }^{31}$ Rahman, "Implementation of the Islamic of State in the Pakistan Milieu," dalam Islam ..., 462. 
sahabat dan kaum muslimin tentang wajibnya menegakkan institusi khilâfah atas prinsip ijmâ. Ijmấ ini berkaitan dengan sistem khilâfah, bukan siapa orang yang dipilih sebagaimana yang dipersoalkan al-Râziq. Islam sama sekali tidak mensyaratkan adanya ijmấ berkenaan dengan orang yang akan dipilih; masalah ini cukup dicapai melalui suara mayoritas. Hal itu merupakan masalah yang bersifat silih-berganti, sedangkan prinsip khilafah yang telah disepakati selamanya tetap, terbentuk melalui satu kali konsensus saja. ${ }^{32}$

Pendapat al-Râziq bahwa Muhammad tidak memerintahkan umatnya untuk mendirikan negara mungkin bisa diterima, tetapi jumlah ayat al-Qur'an tentang mu'âmalah lebih banyak dibandingkan masalah 'aqîdah dan khuluqiyyah. Masalah politik dan negara menyangkut hubungan interpersonal. Setiap individu dan kelompok (golongan) memiliki kepentingan, maka harus ada lembaga kekuasaan yang mengatur. Tentu saja, bentuk dan sistemnya sesuai dengan kebutuhan dan tuntutan jaman. Seandainya Muhammad menetapkan dan mematok seperti itu, tentulah lembaga politik Islam (khilâfah yang ditolak al-Râziq) akan menjadi ketinggalan jaman, sementara prinsip-prinsip ber-mu'âmalah secara jelas telah ditetapkan dalam syariat Islam (al-Qur'an).

Syariat Islam bertujuan menjaga eksistensi agama, jiwa, akal, kehormatan, dan harta. Untuk mewujudkan Islam sebagai rahmat bagi semesta alam membutuhkan sarana berupa institusi politik yang mengatur mu'amalah manusia. Dalam qấidah fiqhiyyah dinyatakan bahwa al-amr bi al-syay' amr bi wasailib (memerintahkan sesuatu berarti memerintahkan sarana untuk mewujudkan sesuatu itu). Oleh karena itu, lembaga politik berupa negara sangat penting dan tidak mungkin dinafikan untuk mewujudkan kemaslahatan umat. Yang terpenting dalam negara adalah penguasa yang memiliki visi kemanusiaan dan menjunjung tinggi kebebasan rakyat dan memenuhi hak dasariah rakyat. Spirit ini sejalan dengan penegasan para ulama bahwa tasharruf al-imâm 'alâ al-ra'iyyah manûth bi al-mashlahah (kebijakan yang diambil oleh penguasa harus didasarkan pada kemaslahatan umat), sebagaimana dikutip Jalâl al-Dîn 'Abd al-Rahmân al-Suyûthî̉ dalam kitabnya al-Asybâh wa al-Nažhâir.

${ }^{32}$ Lihat Mukhtar, "Ali..., 87.

33Lihat Jalâl al-Dîn 'Abd al-Rahmân al-Suyûthî, Al-Asybâh wa al-Nadhâir (Beirût: Dâr al-Kutub, 1983), 83. 